\title{
A TRICKLE-UP ECONOMY: MUTUALITY, FREEDOM AND VIOLENCE IN CAPE TOWN'S TAXI ASSOCIATIONS
}

\author{
Erik Bähre
}

\section{INTRODUCTION}

Every day thousands of minibus taxis roam South Africa's streets, honking dangerously, swerving across lanes, and putting the safety and comfort of their passengers at risk. About 65 per cent of South Africa's commuters depend on taxis. The taxis carry passengers, mostly black South Africans, who are on their way to work, church, shopping, or back home again. Cape Town's taxi drivers have a reputation for being rude, and passengers are usually too intimidated to ask them to turn down the volume of the music a bit, or to object to their swearing, let alone ask them to obey traffic rules. Blom Hansen (2006: 206) described the vibrant and energetic atmosphere in Durban's taxi world where 'the taxi, its colours, and its deafening kwaito signifies much more than a demotic celebration of post-apartheid freedom. It also signifies a new inhabitation of urban space and a new morally ambiguous cultural genre.'

A sense of freedom is also apparent in Cape Town's taxi world, even in driving styles. Especially around Christmas time, when Xhosa people want to go to the Eastern Cape for a short holiday, the driving is wild. The drivers are exhausted, often drunk, and every year they cause numerous fatal accidents. According to the minister of transport, the death toll during Christmas 2010 alone was 1,551 (Stokes 2011; see also Lee 2012). Although these deaths are not all caused by taxis, taxis do play a pivotal role in the lack of safety and are a cause of frustration for their passengers and fellow road users.

How do we conceptualize the freedom that taxi drivers and owners express, along with the freedom that was gained by liberation from apartheid? How did democratization change the taxi world, and how can we understand the relationship between freedom and mutuality? Typically, freedom and community are understood to be mutually exclusive. Communities are expected to offer security to their members at the expense of certain freedoms (Bauman 2001). Yet a wide range of studies has revealed that mutualities and communities can actually contribute to insecurity and even violence. The rise of the Sicilian mafia during the development of an elitist Italian state in the nineteenth century is a clear case. In the absence of state protection, the mafia took upon itself the role of

\footnotetext{
ERIK BÄHRE is Assistant Professor at the Institute of Cultural Anthropology and Development Sociology at Leiden University. He was a researcher at the London School of Economics and a research fellow at the Netherlands Institute of Advanced Studies (NIAS). He is the author of Money and Violence: financial self-help groups in a South African township (Brill 2007). Email: Ebaehre@fsw.leidenuniv.nl
} 
'protecting' the population, albeit in a violent way (Blok 1974). Another example is the 1978 Jonestown Massacre, when nearly a thousand people were killed. These killings have been attributed to the loss of identity through communalism. These so-called 'killer sects' are close-knit communities that can become hotbeds of violence and insecurity (Maniscalco 1997). In South Africa, communities have been drawn into violent patronage networks that redistribute resources provided by the state (Bähre 2007: 51-84).

Although democratization has led to important political liberties, South Africa remains one of the most violent and unequal places in the world. It has some of the world's highest murder, homicide and assault rates, and has the highest rate of reported rapes. ${ }^{1}$ What is the relationship between mutuality and the many insecurities that people experience on a day-to-day basis? The taxi world is a crucial example because it concerns the control of space and mobility. How did the demise of apartheid and the birth of democracy change mutuality within taxi associations?

One of the fallacies of our time is that economies are treated as natural phenomena with natural laws that function more or less independently of society. It is not just that economies are embedded in social relations, or have an impact on mutualities; some sense of mutuality and sociality is essential to the economy (Gudeman 2008; 2009; Hart and Hann 2009; Hart et al. 2010; Maurer 2005) - even high-tech global financial markets depend on mutual recognition (Knorr Cetina and Bruegger 2002; Zaloom 2006). Gudeman (2009) calls for a dialectical approach where mutuality and markets, community and impersonal trade, and belonging and alienation make up the economy. Gudeman (2009: 37) furthermore argues that market models tend to mystify and conceal the mutualities on which economies are based, a point that is also made by Hart (1973; see also Hart et al. 2010) when he points to the interdependencies of informal and formal economies. Ethnographies of South Africa have revealed that democratization, among many other things, gives rise to economies that depend on neopatrimonialism and brokerage (Bähre 2012; James 2011; Niehaus 2006).

Mutualities produce particular economies that cannot exist without some level of social networks of trust, reciprocity and protection to deal with the many uncertainties that business owners have to face. How did the mutualities that are so crucial to the taxi industry emerge? How did they change when the authoritarian apartheid regime collapsed? And what are the consequences of democratization for the nexus of mutuality and economy?

\section{FIELDWORK ON VIOLENCE}

This study is primarily based on my conversations with taxi entrepreneurs, taxi drivers and others involved in taxi associations. During the interviews I was assisted by Edith Moyikwa and Mandisa Kupelu, who, besides helping me with Xhosa-English translations and interpreting the social situations in which conversations and events took place, were also dedicated to my safety. The interviews

\footnotetext{
${ }^{1}$ See $<$ http://www.nationmaster.com $>$. Colombia rates first in 'intentional murders' and South Africa ranks first in all other kinds of murders and homicides.
} 
were held during several research stints between 2005 and 2011, mostly in Cape Town's townships of Khayelitsha, Crossroads, Philippi and Nyanga. The taxi world was, and sometimes still is, very violent. Ethnographers realize that 'violence is a different kind of representational object' (Donham 2006: 4); among others, Daniel (1996: 4, in Donham 2006: 22-6) and Bourgois (2004: 427) were concerned that their representations of violence could be misunderstood as embracing violence, or as the 'pornography of violence'. These concerns are also part of this study.

Several people that I met were key players in taxi associations who had spent time in prison for assault and murder. Our conversations usually took place at people's homes over coffee or a cold drink. Sometimes they took place in the privacy of a car and sometimes at the Kentucky Fried Chicken on Lansdowne Road in Philippi. This meant that the interviews were held on the interviewees' terms in areas with which they were familiar. I was not in charge of the social situation in which the conversations took place, which gave my interlocutors a greater degree of freedom about what to say and what not to say. At the same time, this lack of control over the situation constrained me. Many important questions were left unanswered and some meetings were quite intimidating. One of my most intimidating fieldwork experiences was when I met Mr Bata. Mr Bata owned several taxis and was a board member of one of Cape Town's taxi associations. Edith and I were to meet Mr Bata at the taxi rank with Mlaba, who owned a few taxis himself and had organized the meeting. This was not a good place to talk because it was busy and noisy and would offer no privacy. Therefore, I wanted to drive us to another location and suggested the nearby Kentucky Fried Chicken. It was usually very quiet there and we could easily sit and have a conversation and a cold drink. Edith and Mlaba agreed, but Mr Bata clearly had other plans. From the way in which he gave directions and the way Mlaba responded to his gestures, it was clear that we would not be going to KFC. ${ }^{2}$ Instead, he instructed me to drive in a different direction. At first I continued heading towards KFC - I felt uncomfortable that Mr Bata had immediately taken charge of the situation and had directed me to a place I did not know. Mr Bata calmly persisted and both Edith and Mlaba explained that it was better to follow his instructions, which I did. We ended up at a rather upmarket steakhouse.

When we walked into the steakhouse, it was Mr Bata who decided where we would sit. Once we were seated in one of the booths, without saying anything to me Mr Bata ordered the largest and most expensive meal on the menu. We had not planned to eat and it made us feel very uncomfortable. The three of us ordered a cold drink. I asked Mr Bata about his involvement in the taxi world and he replied that he did not own taxis and that he was merely a consultant in the industry. I am certain that he knew that I knew that he was lying, and again his point was made: Mr Bata was in charge of the situation. He did not explain what this consulting work involved, except that it had something to do with government plans to reform the transport sector. It soon became apparent that he was not going to say much at all. Mlaba had told me previously that Mr Bata knew a lot about the history of the taxi associations and the wars that had taken place between rival associations in the 1980s and 1990s, as well as recent

\footnotetext{
${ }^{2}$ On the politics of gestures, see Herzfeld (2009).
} 
government policies. But when I asked $\mathrm{Mr}$ Bata what he remembered about the fights that had taken place in the 1980s, he said that he did not know much about them. When I asked him if he could tell me anything about specific violent events that had taken place - events that most people working in the taxi world know about - he again said that he did not know anything and claimed to have been away from Cape Town at the time of those specific events. Mlaba was unusually unhelpful.

After some time, the waitress arrived with his meal. Mr Bata had a look at it and, without touching it, asked her to wrap it up as a takeaway: he was not hungry. When the waitress returned with the parcel, he indicated to me that the interview was over, got up, and walked out of the restaurant carrying the food under his arm. It was obvious that I was supposed to pay for it. When we drove back to the taxi rank to drop off Mr Bata and Mlaba, another power display unfolded in the back seat of the car. Mlaba was holding a little box in his hand and $\mathrm{Mr}$ Bata wanted to know what it was. It was headache medication that someone had recommended to Mlaba as being much better than the ones he had at home. He had just purchased it at the nearby pharmacy. Without uttering a word, Mr Bata took the medication out of Mlaba's hand and, after inspecting the box, put it in his own pocket. Mlaba said nothing.

When I met Mlaba a few days later he apologized for Mr Bata's rudeness. It had been a great shock to him that Mr Bata had ordered the most expensive meal and had made me pay for it. He had also felt very uncomfortable and embarrassed. Mr Bata's behaviour came across as a warning to stop my enquiries into the taxi world. After this meeting, it became clear to me that I was becoming too familiar with a world that was extremely violent, and that keeping me out enabled those involved to maintain a unified front that hid the internal politics that are inevitably part of mutualities. I felt that it had become too risky to enquire into events that were still very sensitive, even though many had taken place two decades ago. Fortunately, quite a few people I met were more willing to talk about their involvement in the taxi associations, but nonetheless it was quite common that I could not ask particular questions or that my questions were met with a silence that had to be respected.

\section{COMPETING MUTUALITIES}

The mutualities at the core of the taxi world need to be viewed against the backdrop of the breakdown of apartheid in the 1980s. ${ }^{3}$ This is crucial because this was the period when fierce rivalries between different taxi associations emerged and the monopoly of taxi associations was lost. Of significance was the apartheid distinction between 'rural outsiders' and 'urban insiders'. Apartheid laws not only distinguished between different racial groups, they also distinguished between rural and urban Africans. This rural-urban divide became central to mutuality and violence among the taxi associations. The Urban Areas Act of 1923 severely restricted Africans who wanted to stay in or move to South Africa's cities, and the Abolition of Passes and Co-ordination of Documents Act and the Native Laws

\footnotetext{
${ }^{3}$ See Rodima-Taylor (this issue) on how particular mutualities relate to Tanzania's socialist state.
} 
Amendment Act of 1952 differentiated between rural and urban African rights. The so-called Section 10 rights (which related to the Native Laws Amendment Act) determined that a small group of Africans were allowed to live in the city permanently and gave them some employment advantages. The African majority, who did not have Section 10 rights, were at a disadvantage. For them, unemployment meant that they were forced to leave the city, and were even more vulnerable to police harassment and forced removal than Africans with Section 10 rights (see also Ross 1999; Lee 2005).

These apartheid laws thus distinguished between a select group of Africans - the 'insiders' (Ross 1999: 119) - who had the right to permanently live and work in specific urban townships, and the majority of Africans who were denied those rights. The 'outsiders' were forced to live in 'rural' Bantustans such as the Transkei and Ciskei. They either lived in the city illegally or temporarily, or they could stay only in appalling government 'hostels' (cf. Cole 1987; Ramphele 1991). The division between African insiders and outsiders lasted more than three decades, during which time the legal distinction became a social and economic reality. The 1986 Abolition of Influx Control Act finally put an end to numerous apartheid laws on migration and labour, and to the legal distinctions between urban insiders and outsiders.

African urbanization was pivotal to the breakdown of apartheid and had a profound effect on the demand for transport. African outsiders travelled from the Bantustans hundreds of miles away to their informal settlements on the Cape Flats, from where they commuted to their mostly informal jobs. By the 1980s, the urban African insiders found themselves having to compete for jobs, housing and transport with an increasing number of outsiders. The insiders had de facto lost the small yet crucial legal advantages that the Section 10 rights were still supposed to give them, as it became increasingly impossible for the apartheid state to effectively police these laws. The increased presence of outsiders in urban areas in the wake of a collapsing apartheid state led to fierce fighting across the country. These fights often centred around the taxi associations that were essential for transport between the Bantustans and the urban areas, as well as between illegal urban settlements and work places. ${ }^{4}$

Competing taxi associations sometimes cooperated with gangsters in their attempt to gain control over the most profitable transport routes (Bank 1990; Bonner and Nieftagodien 2001; Khosa 1992). Bank (1990: 83) gives a vivid description of the fights between such rival associations:

The vehicles of the competing sides would be lined up in formation on a large open field. The leaders of both sides would then distribute weapons - guns, pangas and sticks - and as soon as everyone was prepared the signal would be given to attack. These 'battles' always took a heavy toll, leaving dozens of taximen and gangsters either dead or seriously injured. The victors in every case were those who were able to hold their ground the longest.

\footnotetext{
${ }^{4}$ Dugard (2001: 9) suggested that increased taxi violence was due to transport deregulation that took place after the 1987 White Paper on Transport and the 1988 Transport Deregulation Act. This does not seem likely. The taxi wars started in the early 1980s and the Transport Deregulation Act commenced only in June 1990.
} 
Similar fights occurred elsewhere in the country. In Soweto, there had been sporadic taxi fights since the 1970s, and a vicious war erupted in 1982. There were also taxi wars in Johannesburg in 1987 and in the East Rand township of Kathorus, where fifty people were killed and 350 people injured (Khosa 1992: 6-7; Bonner and Nieftagodien 2001: 179). Cape Town's taxi world also became more violent in the 1980s. The Langa, Guguletu and Nyanga Taxi Association (Lagunya) had a monopoly on transport that had probably lasted over thirty years. When Section 10 rights legally came to an end with the Abolition of Influx Control Act in 1986, outsiders immediately organized the rival Western Cape Black Taxi Association (Webta).

Webta started transporting Xhosa migrants from their shanty towns to the centre of Cape Town. The police arrested some of these so-called pirates, but that had little impact. Around the same time, Lagunya operators started defying transport regulations, and subsequently fighting became fierce between the police and the taxi associations, as well as among taxi associations. In 1990, the year in which Nelson Mandela was released from prison, it became clear that the apartheid state was not going to last. In the same year, and possibly as a result of the ever weaker state, there was a violent shoot-out between members of Lagunya and Webta at the Golden Acres, a shopping mall and transport hub in the centre of Cape Town, far removed from residential areas (cf. Dugard 2001: 5).

By 1990, the rivalry between Lagunya and Webta had become a full-blown taxi war. Webta members set up bush camps near Tafelsig and what is now Mitchells Plain. These bush camps remained for two years. Webta taxi owners and drivers worried that staying in their own homes would endanger their families, and so they slept in the bush camps in or underneath their vehicles. The camps - that is how the taxi drivers I talked to referred to them-were used for planning and launching violent attacks on Lagunya members. Mlaba, who in 2010 lived in Nyanga, had been a Webta taxi driver living in one of the camps. He told me that they were able to survive in the camp only because of the support of fellow outsiders who brought drinks and food, often at night. The Webta drivers took care of each other's families. After all, the conflict meant that some of them had no income because they were fighting, and this sometimes forced them to go into hiding. Webta thus developed a social security system for fellow members, providing material and emotional support to members' families and contributing money for funerals.

In some ways the bush camps resembled military strongholds. Mlaba and his fellow Webta members dared to leave the camps only in groups of four or five during the day. It was far too dangerous to go out alone because of Lagunya attacks. But at night they would put on camouflage gear and go to fight Lagunya. Kholiswa, a resident of Khayelitsha who was formerly affiliated to Lagunya, told me:

\footnotetext{
We were very scared of Webta. They always defeated Lagunya. You always had to check the taxi, if it was Lagunya or Webta. If it was a Webta minibus and you do not want to get in, they beat you up, they donner ['assault' in Afrikaans vernacular] you. One day there was a taxi boycott and we went to work with our own car and met a huge crowd. The necklace was ready for us. We said that we went to see my sick mother so they let us go. There are still people in wheelchairs because of these days.
} 
The 'necklace' to which Kholiswa referred was a petrol-infused car tyre forced around the body of a person accused of collaborating with the apartheid regime. The tyre would be set alight, causing severe burns or death. Another resident of Khayelitsha vividly remembered how it was during those 1991-92 fights:

My husband did not dare to sleep at home anymore and instead slept in the bushes. He sometimes stayed there for months in a row. Together with my children I had to flee Cape Town because it was too dangerous to stay in our house. There were shootings in our neighbourhood. We only returned during the summer vacation, but even then I would rarely see my husband. He kept in hiding and was too scared to come to our house. Sometimes people knocked on our front door in the middle of the night to check if he was there so they could kill him. It was very bad. Our men were even accused of cannibalism, of eating a taxi owner from Lagunya while they were hiding in the bushes.

The war between Webta and Lagunya fuelled disputes about the role of the ANC. The police did not intervene in the fights between the two factions and many believed that the apartheid regime actually encouraged them (see also Cole 1987 and the Truth and Reconciliation Commission hearings). Rumour had it that the apartheid government set up Webta as a 'third force' to destabilize society and crush liberation movements. Webta in turn accused the ANC of spreading the rumour that it was a third force supported by the apartheid government. Webta also held the ANC responsible for the story that it had resorted to cannibalism. Mlaba explained: 'They accused Webta people of eating others. They say that Webta took the liver of someone they captured [a Lagunya member] and barbecued it on a spade.' The rumour was very powerful and everybody I interviewed knew about it, many holding it to be true.

In 1992, negotiations led to a peace agreement in which Lagunya and Webta joined to form the Congress of Democratic Taxi Associations (Codeta). However, two years later a group of former Webta members broke away to form the Cape Amalgamated Taxi Association (CATA). They left Codeta because they felt that there were not enough former Webta members on the governing board and that they did not get a fair share of the routes. Part of the 1992 peace agreement had established that former Webta taxi drivers would take passengers to the Nyanga taxi rank and that the former Lagunya members would take them from Nyanga to the city. But the former Webta members wanted to drive their passengers straight to the city centre and back again. According to Dugard (2001), tensions within Codeta heightened after the Independent Electoral Committee issued a cheque of 48,000 South African Rand (R48,000) to Codeta to transport people to the election polls. Former Webta members felt that too many former Lagunya members were given money to transport people to the polling stations. CATA then initiated an aggressive campaign to claim Cape Town's most lucrative taxi routes.

In October 1994, only months after the first democratic elections, CATA was invited to attend an election meeting at the Khayelitsha soccer stadium. Khayelitsha was an important source of business for taxi companies and had been key in the taxi war. It was a profitable taxi route because the township is quite far from the centre of Cape Town and thus relatively high fees could be charged. Initially, members of CATA, the successor of Webta, were reluctant to go to the meeting: they were worried that it would turn into a fight between Codeta (the de facto successor of Lagunya), which was aligned with the victorious ANC, and 
themselves, who were aligned with the Pan African Congress (PAC), which had received far fewer votes during the 1994 elections. Codeta leaders convinced CATA that the meeting would be peaceful. They said that there would be ample numbers of police and even soldiers for protection. According to the CATAaligned taxi owners I spoke to, Codeta had promised that its members would leave their weapons at home: it was supposed to be a festive event celebrating democracy and the victory over apartheid.

CATA members decided to go unarmed, but upon arrival they noticed that the promised soldiers were absent. Some worried when they were seated in a separate section of the stadium and regretted leaving their guns at home. The meeting started with a speech by Winnie Mandela celebrating the victory of the ANC, after which more speakers followed. Then the event ended. According to several eyewitnesses to whom I spoke, Codeta and the ANC made sure that everyone left the stadium except CATA members. Then bullets rained down on them:

We were invited to go to the rally without arms. We saw no need to take guns. This was an ANC rally, but they had planned to massacre us ... the ground was moving from the bullets that hit it. You know how low the taxis were, but people crawled underneath [them] trying to hide.

Press releases from the South African Press Association (SAPA) and Reuters confirm the violent encounter. SAPA ${ }^{5}$ reported that the feud between Codeta and CATA had 'erupted into open warfare at the weekend when ten people were killed in the Khayelitsha stadium'. That same day, SAPA reported that the police recovered 162 bullets at the site and that ten men were killed and twenty-three injured: 'It now appears that one or two shots were fired inside the stadium as people started to leave, followed by an all-out gunfight ... These were bullets and casings of AK47, R4 and $9 \mathrm{~mm}$ weapons.' A press release from Reuters mentioned that 'all but one of the victims belonged to the Cape Amalgamated Taxi Association [CATA] which recently broke away from the Congress of Democratic Taxi Associations [Codeta]'. ${ }^{6}$

The Khayelitsha massacre features prominently in the oral history of CATA taxi owners but received surprisingly little attention in the media, even though it was crucial to the escalation of violence. All the CATA members whom I interviewed held the ANC responsible. They said that it was a trap organized by Codeta, the ANC and the South African National Civic Organization (SANCO). For them, the Khayelitsha massacre confirmed that the ANC cared only for the urban insiders. They took it as another sign that they, the rural outsiders, were still not welcome in Cape Town. The fighting continued, leading to more shootings and taxi drivers throwing petrol bombs at rival taxi ranks or other passenger pickup sites. Not until years later, in the late 1990s, did taxi associations stop their violent fights and more or less agree to divide their turf along the R300 highway. Codeta was allowed to transport people from Khayelitsha and to most locations north of the R300, while CATA would operate mostly in the areas south of the R300. But the fighting never stopped completely.

\footnotetext{
${ }^{5}$ SAPA released several statements on 19 October 1994.

${ }^{6}$ See also Ntsebeza (2005: section 8).
} 
When the apartheid state lost power, new mutualities arose that offered taxi owners and their drivers protection and mutual support. These mutualities helped them set up their businesses and offered social security as well as physical and emotional support during tough times. At the same time, these mutualities were mobilized by relatively advantaged urban insiders who saw their businesses threatened by rural outsiders.

\section{THE RECAP}

The post-apartheid government tried to regulate the taxi industry through what taxi owners call the Recap, or the Taxi Recapitalization Programme (TRP) (see Schalekamp et al. 2010; Walters 2008). How did this affect mutuality within the taxi industry? One of the aims of the Recap was to break up or at least marginalize taxi associations, formalize the industry, combat violence, and reduce a wide range of illegal and unsafe practices. At the same time, however, the Recap relied on mutuality in the taxi world.

The Recap was established in the late 1990s, and its implementation was accelerated in the 2000s as part of the preparation for the 2010 FIFA World Cup (Walters 2008: 102). ${ }^{7}$ It had to formalize the industry and 'reduce the taxi vehicles ... from about 120,000 to 85,000 ' (Walters 2008: 106). The idea was that fewer taxis on the road meant less competition and a more sustainable livelihood. The government would distribute routes to individual taxi owners using a tendering system, even though experiences elsewhere suggested that this would increase transport costs (Walters 2010: 364). Regulating the industry meant that minibus taxis had to comply with stricter technical requirements regarding road safety, drivers had to pay income taxes, and owners had to pay their drivers proper wages and insure their vehicles (Walters 2008: 105-8). A big sticker on the vehicle served as identification to customers that it plied a licensed route. Police officers monitored taxis more intensely than before by stopping vehicles to check if they were roadworthy, if the operators had a driver's licence, passenger insurance was paid, vehicles were not overloaded and technical requirements were met, as well as verifying a wide range of other regulations.

The taxi Recap was intended to stop illegal practices and make taxi transport cheaper and safer. This was not achieved by liberalizing the taxi industry, but by implementing a wide range of restrictive measures. A key result of the Recap was that it made the taxi world into a bigger market for loans, insurance policies and vehicles. For example, the Recap declared that the older Toyota Siyaya models were unsafe and forced owners to replace them with newer, more expensive vehicles. The Recap subsidized the scrapping of older vehicles, giving the owner R45,000 (previously R50,000) for every vehicle that was taken off the road and scrapped. The R45,000 could be used as a subsidy for buying a new vehicle. In theory, any vehicle that met a number of standards would suffice, but in practice these rules meant that one had to buy a Toyota model or a much more expensive Mercedes. Many taxi owners felt that the Recap forced them to buy expensive

\footnotetext{
${ }^{7}$ On the legislative process, see Behrens and Wilkinson (2003), Schalekamp and Behrens (2010) and Wilkinson (2010).
} 
vehicles that they did not need. This regulated financialization of the industry generated heavy costs for individual taxi owners. Andries, for example, was a member of CATA and took over his father's business after he died in a car accident. The Toyota Quantum that replaced his older Toyota Siyaya model cost R250,000, nearly R100,000 more than the Siyaya. Andries did not feel any need to buy it; he was perfectly happy with the older Siyaya. But the government would eventually prevent him from continuing his business if he did not purchase the new Quantum. Andries did not have enough cash, meaning that he had to take out a loan for nearly R200,000. He also had to take out third party insurance, passenger liability insurance and comprehensive insurance. The insurance had to be taken out as part of the loan to limit the bank's risk. The comprehensive insurance covered the costs of repairing or replacing the vehicle in case of an accident, and thus would ensure that the loan's collateral, i.e. the vehicle, would not be lost. Andries had to spend R1,800 a month on insurance premiums alone, which was more than the legal minimum wage. He bought the insurance policies from the brother of a fellow CATA member, but later found out that it would have been cheaper to contact the insurance company directly.

Andries was not quite sure if the insurance was helpful or not. A month prior to our interview in December - the busiest month of the year - one of his new taxis was involved in a car accident. The vehicle had to be taken off the road and parked with a panel beater, who eventually was not allowed to fix it. Instead, Andries had to provide the insurance company with quotes from three different panel beaters listed by the insurer. Andries did not have time to do this; December was the busiest month of the year and he had no time for the bureaucracy. He could attend to this only in January, meaning that his vehicle had to stay off the road until then. Andries did not like the fact that he could not choose his own panel beater. Andries thought that many of the new Toyota Quantum models ended up on the scrapheap because they were too expensive to repair. The technology and parts were too complex, which meant that the Quantum would be written off quickly.

The formalization of the taxi industry made it possible to provide loans for purchasing a taxi, which was beneficial to the financial sector, to car manufacturers, particularly Toyota, and to car dealers. Although these loans were individual, and although individual taxi owners were personally responsible for the vehicle and the loan, the taxi association board members were the ones who made the deals. The board member of one taxi association told me that he was engaged in talks with a Toyota dealer in Cape Town as well as with one of South Africa's largest banks (ABSA) and the Cape Metropolitan Council about the purchase of 1,500 Toyota vehicles for his association members. The deal amounted to over R200 million (approximately $€ 20$ million). The Recap thus made taxi associations into powerful and lucrative brokers between taxi owners, car dealers, banks and government agencies. The Recap enabled the government to create a multibillion-euro industry that taxi owners and passengers eventually had to pay for. Rumour had it that the taxi associations' leaders were rewarded with large bribes in return for securing these deals.

Previously, taxi associations had been mutual benefit societies that provided financial, moral and practical support when members or their relatives died. For example, members of Kiki Murray, a taxi association that was part of CATA, paid R100 a month into a funeral fund, and an additional R100 when a 
member died. The bereaved family received approximately R20,000 in cash and goods from the association. ${ }^{8}$ Codeta had membership fees of up to R30,000 and part of that money was used for social security. CATA's burial society provided R55,000 when a taxi owner or their spouse died, and R10,000 when a taxi owner's parent or child died. These mutual benefit societies became potential markets for insurance companies. The associations not only provided the insurance companies with new clients, but also carried out a large part of the administration, thus limiting the insurer's organizational costs (cf. Bähre 2012).

The Recap meant that police control was intensified. Taxi owners received fines of up to R5,000 for misdemeanours and their vehicles were impounded quickly. I was told that one reason why the police were so strict was that Recap regulations became a means to solicit bribes. The heavy fines and ease of impounding vehicles could destroy a taxi owner's business, making it very attractive to bribe police officers. Many taxi owners had experience with police officers soliciting bribes in return for overlooking an administrative offence.

Ingrid was one of the many taxi owners who experienced strict government regulations. One day her driver told her that the police had impounded her taxi, so she went to the magistrate's court to get it back. Although Ingrid's command of English was very good, her expectation was that the white magistrate would be more likely to return the vehicle to her if she conformed to the stereotype of a poorly educated black township woman. She decided to go to the court barefoot and dressed in shabby clothes, and purposely adopted a strong Xhosa accent. This charade was intended to give the magistrate the impression that she had no idea of what had happened to her. In heavily accented English she explained to the magistrate how poor she was and how much she was suffering. 'I sufara!' (I suffer!), she told the magistrate. Ingrid's husband, who was accompanying her, was very embarrassed but remained quiet. The charade worked. Ingrid managed to convince the magistrate that she had acted in good faith and she got her vehicle back without having to pay a fine. But such manoeuvres offered only partial relief.

The Recap put financial pressure on taxi owners and affected mutuality within the industry's associations. It appeared that the Recap strengthened dependence on taxi associations and contributed to the criminalization of the industry. In 2005, a committee of inquiry examined the continued taxi violence in Cape Town and reported its findings to the Premier (Ntsebeza 2005). The investigation revealed that taxi associations had become more powerful and more criminal than they had been before. They were now run as a mafia and the associations' leaders had become warlords. The money that the associations had collected over the years not only was a social security fund, but now had become a war chest as well. The warlords used the money to hire hitmen and paid up to R12,000 for a single contract to kill someone. They used the money to bribe police officers to make incriminating evidence disappear. They paid for legal fees, ammunition and traditional healers who gave spiritual protection. The remaining money would go into the warlords' pockets. The committee of inquiry listed a wide range of accusations against the operating licensing board responsible for providing taxi permits. The board members were accused of accepting bribes and gaining personally from their close cooperation with the warlords. The taxi associations

\footnotetext{
${ }^{8}$ Prices in 2010 .
} 
also formed their own hit squads by recruiting former soldiers from the military wings of the ANC and the PAC. The former ANC soldiers worked for the ANCaligned Codeta, and the former PAC-aligned soldiers for CATA. In order to supplement their war chests, warlords demanded money from taxi owners. The owners had to pay a 'joining fee' of between R10,000 and R60,000, a monthly fee of R1,000, another R100 that was due every Monday and Wednesday, and a daily fee of R10. These amounts were for each vehicle. The committee of inquiry encountered what it described as a 'culture of fear'. People were reluctant to testify, even though anonymity was guaranteed. One of the men who testified before the committee was murdered soon afterwards; the committee suggested that this might have happened due to his testimony, which made people even more reluctant to talk (Ntsebeza 2005). It would be an understatement to say that the Recap did not live up to its promise. The financial burdens for taxi owners increased, and the Recap made it possible for taxi associations to become powerful brokers between financial companies, car dealers, government agencies and dependent taxi owners.

\section{MUTUALITY IN A SHRINKING MARKET}

In 2005 and 2006, several people were killed in a taxi feud in Kraaifontein, and in 2007 there were fights between CATA and Codeta over the Bellville-Kraaifontein route in which the ANC was accused of siding with Codeta (Farber 2007). There was a shoot-out between taxi drivers in Bellville in 2009, and in August 2010 two taxi drivers were killed in Nyanga. By the end of 2013, more people were killed in taxi-related feuds, which led to, among other things, the temporary closure of the Bellville taxi rank (cf. Mtyala 2013; Sibanda 2013). Although the taxi world today is not as violent as it was in the 1990s, there are still regular fights that reveal shifting relations between and within taxi associations, the changing transport market, and the consequences of new transport policies introduced by the state.

In 2006, the South African National Department of Transport developed a new set of transport policies that determined that the state would spend up to R14.5 billion on developing a nationwide Integrated Rapid Public Transport Network (IRPTN) (de Bruyn 2010). Part of the IRPTN was a network of bus services, the Bus Rapid Transit (BRT), which operated from the townships to the centre of Cape Town. Once the BRT was established, taxis would effectively be banned from the city's highways and other major routes (Schalekamp et al. 2010; Schalekamp and Behrens 2010; see also Zuma 2009) and would be limited to operating within townships, or between townships and new BRT stations. In other words, taxis would lose the longest and most profitable routes.

In December 2008, the BRT caused severe tensions within the taxi world: the associations organized protests in which buses were stoned, a taxi was burned, and protesters were shot at with rubber bullets by the police (Cape Argus 2008). The Western Cape Minister of Community Safety and former executive mayor of the City of Cape Town held a meeting with taxi owners in Milnerton. When the minister tried to speak he was shouted down, and one of the leaders of a taxi association declared:

We call you, go sit and listen. They put a piece of fat in your mouth [bribe] so shut up, otherwise the fat falls out of your mouth. We do not let you take away our kids' future. 
We will defend our routes; we started them and if you will put up cameras [to survey the routes] we will destroy them.

In order to establish their power, the taxi associations decided on the spot to have a taxi strike and to sabotage trains by stealing railway tracks and cables (cf. Mlandu 2009; Cape Argus 2009).

When implementing the BRT, the national government consulted the South African National Taxi Council (SANTACO), which it had elevated to be the legitimate representative of all South African taxi associations. CATA and Codeta both felt that SANTACO did not represent them and accused SANTACO of corruption and of taking bribes. In 2009, the deputy chairperson of SANTACO was gunned down. In 2012, SANTACO president Jabulani Mthembu stepped down after an audit revealed that he had stolen nearly R1 million from the association. In that same year, SANTACO made an attempt to become a shareholder in a new car manufacturing plant, and allegedly benefited from a deal with a petrol company (SAPA 2009; 2012; Sibanyoni 2012; Xaba 2012). ${ }^{9}$

A group of taxi associations established a rival organization: the South African National Taxi Association (NTA). The NTA vehemently protested against the BRT and in 2010, just before the World Cup, the NTA chairperson of the Western Cape proclaimed at a meeting with 500 taxi drivers: 'Whoever imple-

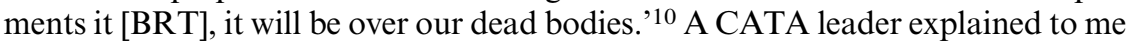
that the government would fail to 'domesticate' the NTA: 'SANTACO, they are the lion in the zoo. We, NTA, are the lion in the bush.'

The BRT also caused tensions within CATA. The BRT would take away the longer and most profitable taxi routes and as a result minibus taxis would have to find new routes, such as transporting people within townships. However, the socalled amaphela taxis were already operating within the townships. Amaphela is Xhosa for cockroaches and refers to the way in which these cars, usually Toyota Cressida sedans, scavenge the streets in search of passengers to take home or to the local taxi rank. The amaphela were organized by Kiki Murray, which was part of CATA. Before the Recap, the amaphela had driven without licences for years, possibly decades. Now they were more formalized and had started operating with a licensing system. ${ }^{11}$

The amaphela taxis were concerned that their turf would be taken over by the minibus owners. One of the leaders of Kiki Murray explained to me that, if CATA and Codeta come here [in the township], there will be a war. We are not going to fold our arms and wait for the government to steal our bread.' The CATA branches that represented the minibus taxis in turn accused Kiki Murray of trying to control their taxi ranks and routes. A CATA member and owner of

\footnotetext{
${ }^{9}$ See also < http://mg.co.za/article/2009-09-08-killing-of-santaco-official-not-related-to-brt $>$.

${ }^{10} \mathrm{Cited}$ in the Mail and Guardian: < http://mg.co.za/article/2010-03-24-taxi-operators-notexcluded-from-world-cup $>$.

${ }^{11}$ See also the 2005 report of the commission of inquiry (Ntsebeza 2005). On the status of amaphela in 2013, see the speech given by Robin Carlisle, Minister of Transport and Public Works of the Western Cape Province, at < http://www.westerncape.gov.za/gc-news/412/9840>, accessed 16 January 2014.
} 
three minibus taxis said that the minibus owners had set up the ranks and that they had consulted with the communities. She therefore felt that only the minibus owners were entitled to bring people from the smaller ranks to the bigger ranks, such as the one in Bellville, from where they could continue their journey. The minibus owners would not allow the amaphela to push them away.

In 2010, Kiki Murray began debating whether it was better to leave CATA and start a separate association. At the time of writing, this still has not happened, and it is unlikely that it will. The licensing and permit system and other negotiations with the Cape Metropolitan Council are conducted by CATA, and if Kiki Murray were to leave CATA its members would risk losing their taxi licences.

In October 2013, the fights escalated between the minibus owners of CATA and the amaphela owners. Several taxi owners were killed between October and December: two people were shot in their homes in Old Crossroads; one man was killed at the Nyanga taxi rank; one man was killed in the township of Lusaka; and another man was shot dead in Kraaifontein. ${ }^{12}$ These were all owners of minibus taxis, and although nobody was charged for the murders, rumour had it that they were instigated by the amaphela. During this period, the Bellville taxi rank was closed for some time and the police were called in in an attempt to avoid any further escalation of violence. A CATA member and minibus owner told me: 'In December I had to go to Bellville in order to get a vehicle crushed and replaced [as part of the Recap]. But the CATA board had no time for me. They were too busy. They will not let amaphela take over the Bellville rank. You know, moss, that is gangster paradise.'

The BRT had important consequences for mutuality in the taxi industry. It led to the formation of two national taxi associations: SANTACO, which was accused of corruption and siding with the government and businesses; and the NTA, the only legitimate representative for CATA and Codeta. It also caused, or at least intensified, tensions within CATA: instead of having only the rivalries between CATA and Codeta, rivalries within CATA became more pronounced. However, due to CATA's dependence on the state, these rivalries did not lead to a formal split, although they were rumoured to be behind the violent outbreaks at the end of 2013.

\section{CONCLUSION: DEFINING THE TRICKLE-UP ECONOMY}

Economic inequality and violence still permeate South African society, forcing taxi owners to make a living in extremely precarious circumstances. Mutualities ideally offer security and protection, and enable markets that are key to people's livelihoods. Yet mutuality is also causing insecurity, is directly connected to violence, and has not prevented increased economic marginalization.

\footnotetext{
${ }^{12}$ Some taxi murders that took place in 2013 were reported in the local news. See, for example, $<$ http://ewn.co.za/2013/10/29/Illegal-operators-causing-Delft-taxi-violence >; <http://ewn.co.za/ 2013/11/12/Nyanga-taxi-driver-murdered > ; < http://ewn.co.za/2013/11/07/Taxi-violence-leavesDelft-community-scared >; <http://ewn.co.za/2013/11/04/Three-shot-in-suspected-taxi-violenceincident $>$; $\quad<$ http://www.news24.com/SouthAfrica/News/Man-held-for-Cape-Town-shooting$20131108>$; < http://www.iol.co.za/news/crime-courts/nyanga-taxi-driver-shot-dead-1.1605544\#. UtkxINGA2Uk >; all accessed 17 January 2014.
} 
Rather than enjoying the freedoms that we associate with the sector and the unambiguous security of mutuality, the taxi world is now at the centre of what can best be defined as a trickle-up economy. Trickle-down economics, also dubbed 'Reaganomics', falsely claims that tax cuts and a shrinking welfare state benefit people with low incomes: the money of the wealthy eventually trickles down to the poor. I use the concept of trickle-up economics to highlight how South African taxi owners find themselves in a reversed situation. More so than ever before in their history, the associations' money trickles up to the state, to businesses and to taxi association leaders. Over the past twenty years, the members of taxi associations have become a key economic resource for the state through taxes, licences and fines; for law enforcement officers through bribes; for warlords through 'membership fees' and protection rackets; for banks through obligatory credit; for insurance companies through obligatory policies; and for car manufacturers and dealers through obligatory vehicle replacement. This trickle-up economy is founded on three interdependent dynamics.

First, trickle-up economics relies on mutualities to allocate cash to the state, private companies and taxi association leaders. During apartheid, the mutual associations of taxi owners collected money for social security benefits and physical protection against violent competitors. But in the late 1990s, and even more so in the twenty-first century, the association leaders became powerful brokers. The leaders have used, sometimes violently, the associations' mutuality to generate profits for themselves and for the financial sector, and as a means to collect state revenues through taxation and the distribution of permits. The mutual relations that make up the taxi associations not only offer free labour - collecting money at taxi ranks, for example - but also control the market. It is impossible to run a taxi without being a member of an association. The so-called 'pirates' who try to do so risk being killed. The taxi associations have become aggressive protection rackets mobilized by profit at the expense of drivers and owners.

Second, trickle-up economics relies on the dialectics of market and community, as well as on hybrid forms of formality and informality (on this point, see Bayart 1993; Hart 1973; Gudeman 2009; Reno 1995). In this scenario, formal financial companies and government agencies cooperate with informal and even criminal associations. ${ }^{13}$ The state cooperates with criminal taxi associations sometimes out of convenience, sometimes as part of corruption, and sometimes out of fear. Equally, businesses rely on violent association leaders. Banks, insurers, car manufacturers and car dealers cooperate with suspicious taxi association leaders in order to sell their products to the thousands of members they represent. The fact that formal businesses and government institutions depend on informal networks and illegal practices appears to be key to trickle-up economics. Mutuality seems to be key to our understanding of the economy as it reveals the interdependencies of formal and informal processes (see also Bähre 2012; Guyer 1999; Hull and James 2012).

Third, trickle-up economics is characterized by strong economic intervention by the state. The taxi world is far from liberal but only in the past three decades

\footnotetext{
${ }^{13}$ See also James (2011) on the return of the broker and Niehaus (2006) on neopatrimonialism in South Africa.
} 
has it come under tight government control. It is safe to say that the government's Recap policies have contributed to the financial exploitation of taxi owners, drivers and passengers. The BRT policies try to limit where taxis can operate and threaten to take away the most profitable markets. Simultaneously, state policies have increased the financial burden on taxi owners by forcing them to incur huge debts for 'safe' new vehicles and obligating them to purchase broad insurance coverage, while this wide range of fees and taxes has made taxi owners increasingly vulnerable to the solicitation of bribes by the police. The added financial burden on taxi owners has not led to large-scale protests, possibly because government organizations have implemented these measures in cooperation with taxi association leaders. Protests within and between the mutualities that make up the taxi world emerged only when there was a threat to limit the taxi associations' turf. In trickle-up economics, mutuality is charged with violence while serving corporate interests and offering a limited defence against the state's economic control. Taxi drivers today still defy traffic regulations, still play loud music, and are still rude to their passengers. But over the past thirty years, these freedoms have lost their political and socio-economic foundations.

\section{ACKNOWLEDGEMENTS}

This study was supported by Deborah James' ESCR-funded project 'The Anthropology of Economy in Post-Apartheid South Africa' and a grant from the Netherlands Institute for Advanced Study in the Humanities and Social Sciences (NIAS). I wish to acknowledge Tazuko van Berkel, Jill Haring, Jan-Bart Gewald, Robert Ross and the anonymous Africa referees for their stimulating suggestions and inviting comments.

\section{REFERENCES}

Bähre, E. (2007) Money and Violence: financial self-help groups in a South African township. Leiden and Boston MA: Brill.

(2012) 'The Janus face of insurance in South Africa: from costs to risk, from networks to bureaucracies', Africa 82 (1): 150-67.

Bank, L. J. (1990) "The making of the Qwaqwa "mafia"? Patronage and protection in the migrant taxi business', African Studies 49 (1): 70-93.

Bauman, Z. (2001) Community: seeking safety in an insecure world. Cambridge: Polity.

Bayart, J.-F. (1993) The State in Africa: the politics of the belly. London and New York NY: Longman.

Behrens, R. and P. Wilkinson (2003) Metropolitan Transport Planning in Cape Town, South Africa: a critical assessment of key difficulties. Cape Town: Urban Transport Research Group, Faculty of Engineering and the Built Environment, University of Cape Town.

Blok, A. (1974) The Mafia of a Sicilian Village, 1860-1960: a study of violent peasant entrepreneurs. New York NY: Harper and Row.

Blom Hansen, T. (2006) 'Sounds of freedom: music, taxis, and racial imagination in urban South Africa', Public Culture 18 (1): 185-208. 
Bonner, P. and N. Nieftagodien (2001) 'The Truth and Reconciliation Commission and the pursuit of "social truth": the case of Kathorus' in D. Posel and G. Simpson (eds), Commissioning the Past: understanding South Africa's Truth and Reconciliation Commission. Johannesburg: Witwatersrand University Press.

Bourgois, P. (2004) 'The continuum of violence in war and peace: postCold War lessons from El Salvador' in N. Scheper-Hughes and P. Bourgois (eds), Violence in War and Peace: an anthology. Oxford: Blackwell.

Cape Argus (2008) 'Commuters flee rampaging taxi drivers', 9 December.

- (2009) 'Taxi strike sent a clear message - bosses', 20 February.

Cole, J. (1987) Crossroads: the politics of reform and repression 1976/1986. Johannesburg: Ravan Press.

Daniel, V. E. (1996) Charred Lullabies: chapters in an anthropology of violence. Princeton NJ: Princeton University Press.

de Bruyn, C. (2010) 'SA to spend R14,5bn on Integrated Transport Networks', Engineering News, 7 July.

Donham, D. L. (2006) 'Staring at suffering: violence as a subject' in E. G. Bay and D. L. Donham (eds), States of Violence: politics, youth, and memory in contemporary Africa. Charlottesville VA and London: University of Virginia Press.

Dugard, J. (2001) From Low Intensity War to Mafia War: taxi violence in South Africa (1987-2000). Violence and Transition Series 4. Cape Town: Centre for Studies of Violence and Reconciliation.

Farber, T. (2007) 'War over routes', Mail and Guardian, 21 May.

Gudeman, S. (2008) The Anthropology of Economy: community, market, and culture. Oxford: Blackwell.

(2009) 'Neccessity or contingency: mutuality and market' in K. Hart and C. M. Hann (eds), Market and Society: the great transformation today. Cambridge: Cambridge University Press.

Guyer, J. I. (1999) Marginal Gains: monetary transactions in Atlantic Africa. Chicago IL and London: University of Chicago Press.

Hart, K. (1973) 'Informal income opportunities and urban employment in Ghana', Journal of Modern African Studies 11 (1): 61-89.

Hart, K. and C. M. Hann (2009) 'Introduction: learning from Polanyi' in K. Hart and C. M. Hann (eds), Market and Society: the great transformation today. Cambridge: Cambridge University Press.

Hart, K., J.-L. Laville and A. Cattani (2010) 'Building the human economy together' in K. Hart, J.-L. Laville and A. Cattani (eds), The Human Economy: a citizen's guide. Cambridge: Polity.

Herzfeld, M. (2009) 'The cultural politics of gesture: reflections on the embodiment of ethnographic practice', Ethnography 10 (2): 131-52.

Hull, E. and D. James (2012) 'Introduction: local economies and citizen expectations in South Africa', Africa 82 (1): 1-19.

James, D. (2011) 'The return of the broker: consensus, hierarchy, and choice in South African land reform', Journal of the Royal Anthropological Institute 17 (2): 318-38.

Khosa, M. M. (1992) 'Routes, ranks and rebels: feuding in the taxi revolution', Journal of Southern African Studies 18 (1): 232-52. 
Knorr Cetina, K. and U. Bruegger (2002) 'Global microstructures: the virtual societies of financial markets', American Journal of Sociology 107: 905-50.

Lee, R. (2005) 'Reconstructing "home" in apartheid Cape Town: African women and the process of settlement', Journal of Southern African Studies 31 (3): 611-30.

(2012) 'Death in slow motion: funerals, ritual practice and road danger in South Africa', African Studies 71 (2): 195-211.

Maniscalco, M. L. (1997) 'A new global risk: the rise of the killer sects', International Review of Sociology 7 (3): 485-97.

Maurer, B. (2005) Mutual Life, Limited: Islamic banking, alternative currencies, lateral reason. Princeton NJ and Oxford: Princeton University Press.

Mlandu, L. (2009) 'Taking on the taxis', iAfrica.com News, 13 March.

Mtyala, Q. (2013) 'Cape taxi rank faces shutdown over violence', Times Live, 28 March. < http://www.timeslive.co.za/thetimes/2013/03/28/cape-taxi-rankfaces-shutdown-over-violence $>$, accessed 18 July 2014.

Niehaus, I. (2006) 'Doing politics in Bushbuckridge: work, welfare and the South African elections of 2004', Africa 76 (4): 526-48.

Ntsebeza, D. (2005) Committee of Inquiry into the Underlying Causes of Instability and Conflict in the Minibus Taxi Industry in the Cape Metropolitan Area: report to the Premier 31 August 2005. Cape Town: no publisher.

Ramphele, M. (1991) 'The politics of space: life in the migrant labour hostels of the Western Cape'. PhD thesis, University of Cape Town.

Reno, W. (1995) Corruption and State Politics in Sierra Leone. Cambridge: Cambridge University Press.

Ross, R. (1999) A Concise History of South Africa. Cambridge: Cambridge University Press.

SAPA (2009) 'Taxi boss gunned down', South African Press Association (SAPA), 5 September.

_ (2012) 'Santaco president axed', IOL news, 21 May.

Schalekamp, H. and R. Behrens (2010) 'Engaging paratransit on public transport reform initiatives in South Africa: a critique of policy and an investigation of appropriate engagement approaches', Research in Transport Economics 29: 371-8.

Schalekamp, H., R. Behrens and P. Wilkinson (2010) 'Regulating minibus-taxis: a critical review of progress and a possible way forward.' Proceedings of the 29th Southern African Transport Conference (SATC 2010), 16-19 August, Pretoria, South Africa.

Sibanda, J. J. (2013) 'Taxi violence hits Cape Town', News 24, 14 November. $<$ http://www.news24.com/MyNews24/Taxi-Violence-Hits-Cape-Town-201311 $14>$, accessed 18 July 2014.

Sibanyoni, M. (2012) 'Taxi stake uproar: Chinese not keen to offer share in plant', Sowetan, 20 November.

Stokes, G. (2011) 'Local roads claim 1551 lives this Christmas', FA News, 18 January.

Walters, J. (2008) 'Overview of public transport policy developments in South Africa', Research in Transport Economics 22: 98-108.

- (2010) 'Is the bus transport contracting system in South Africa leading to trusting relationships between contracted parties? An analysis of funding issues 
and the impact on relations between government and operators', Research in Transport Economics 29: 362-70.

Wilkinson, P. (2010) 'The regulatory cycle stalled? An assessment of current institutional obstacles to regulatory reform in the provision of road-based public transport in Cape Town, South Africa', Research in Transport Economics 29: 387-94.

Xaba, V. (2012) 'ANC MP in taxi petrol dispute: claim that deal was to benefit executives', Sowetan, 13 January.

Zaloom, C. (2006) Out of the Pits: traders and technology from Chicago to London. Chicago IL and London: University of Chicago Press.

Zuma, J. G. (2009) State of the Nation Address of June 3 2009. Cape Town: Parliamentary Monitoring Group.

\section{ABSTRACT}

Mutuality is at the heart of the continued violence and inequality in South Africa. This historical and anthropological analysis of Cape Town's taxi associations reveals how mutuality has become strongly connected with violence and economic marginalization. The breakdown of apartheid led to new mutualities along the rural-urban divide, which resulted in taxi wars between 'urban insiders' and 'rural outsiders'. After liberation from apartheid, mutuality within Cape Town's taxi associations became a central issue in government policy and commercial interests, which contributed to taxi associations becoming mafia-like organizations. This analysis reveals that taxi owners today find themselves in a trickle-up economy characterized by: violent and shifting mutualities; the embrace of illegality and informality as being vital to doing business; and strong economic intervention by the state.

\section{RÉSUMÉ}

La mutualité est au cœur de la violence et de l'inégalité qui persistent en Afrique du Sud. Cette analyse historique et anthropologique des associations de taxis de Cape Town révèle comment la mutualité est devenue fortement liée à la violence et la marginalisation économique. La désintégration de l'apartheid a débouché sur de nouvelles mutualités construites sur le clivage urbain-rural qui ont entraîné des guerres de taxis entre les " autochtones urbains » et les « étrangers ruraux ». Après la libération de l'apartheid, la mutualité dans laquelle s'inscrivaient les associations de taxis de Cape Town est devenue un enjeu majeur, dans la politique gouvernementale et les intérêts commerciaux, qui a contribué à la mafiosisation des associations de taxis. Cette analyse révèle que les propriétaires de taxis se trouvent dans une économie qualifiée de « trickle-up » (ascendante), caractérisée par : des mutualités violentes et changeantes, l'acceptation de l'illégalité et de l'informalité comme essentielles à la conduite des affaires, et la forte intervention de l'État dans l'économie. 